\title{
Efeitos do ágar no crescimento de explantes e na formação de calos em morfos pigmentares de Gracilaria domingensis (Kützing) Sonder ex Dickie (Gracilariales, Rhodophyta) ${ }^{1}$
}

\author{
FERNANDA RAMLOV ${ }^{2}$, ESTELA M. PLASTINO ${ }^{3}$ e NAIR S. YOKOYA ${ }^{2,4}$
}

(recebido: 07 de agosto de 2008; aceito: 24 de junho de 2009)

\begin{abstract}
Effects of agar on explant growth and callus formation in color morphs of Gracilaria domingensis (Kützing) Sonder ex Dickie (Gracilariales, Rhodophyta)). The effects of agar concentrations on growth and callus formation were studied in axenic cultures of female gametophytes of green and red morphs of Gracilaria domingensis (Kützing) Sonder ex Dickie. Unialgal cultures of both color morphs were maintained in sterilized seawater (30-32 psu) enriched with a quarter-strength of von Stosch's solution (VSES 25\%), $22 \pm 2{ }^{\circ} \mathrm{C}$, photoperiod of $14 \mathrm{~h}$, irradiance of 50-80 $\mu$ mol photons $\mathrm{m}^{-2} \mathrm{~s}^{-1}$. To obtain axenic explants, apical and intercalary segments of the green and red morphs were cultured for $48 \mathrm{~h}$ in VSES $25 \%$ medium with addition of antifungal and antibiotic solution, washed with a solution of sterile seawater with $0.5 \%$ of sodium hypochlorite and $200 \mu \mathrm{L} \mathrm{L}^{-1}$ of detergent during 20 seconds. In order to evaluate the effects of agar, apical and intercalary segments were inoculated into modified ASP 12-NTA synthetic medium with agar concentrations ranging from zero to $1.0 \%$. Addition of agar to the culture medium inhibited the growth of apical segments of both morphs as well as the growth of intercalary segments of green morph. In general, growth rates of thallus segments were inversely proportional to agar concentration. Treatments with agar induced the formation of three types of callus, denominated in accordance with the explant region which gave rise to the callus: apical, basal, and intermediate calluses. Moreover, presence of agar is essential to induce intermediate and apical calluses. Concentrations of $0.5 \%$ and $0.7 \%$ of agar were the optimal values for the induction of basal and intermediate calluses of greem morph, respectively. The results indicated that agar has a regulatory role on morphogenetical processes in color morphs of G. domingensis.
\end{abstract}

Key words - agar, callus, color morphs, Gracilaria domingensis, Rhodophyta

RESUMO - (Efeitos do ágar no crescimento de explantes e na formação de calos em morfos pigmentares de Gracilaria domingensis (Kützing) Sonder ex Dickie (Gracilariales, Rhodophyta)). Os efeitos da concentração de ágar no crescimento de explantes e na formação de calos foram avaliados em culturas axênicas de gametófitos femininos de morfos de coloração verde e vermelha de Gracilaria domingensis (Kützing) Sonder ex Dickie. Culturas unialgáceas foram mantidas em água do mar esterilizada (30-32 ups) enriquecida com 25\% da solução de von Stosch (VSES 25\%), $22 \pm 2{ }^{\circ} \mathrm{C}$, fotoperíodo de $14 \mathrm{~h}$, irradiância de 50-80 $\mu \mathrm{mol}$ de fótons $\mathrm{m}^{-2} \mathrm{~s}^{-1}$. Para a obtenção de explantes axênicos, segmentos apicais e intercalares dos dois morfos foram cultivados por $48 \mathrm{~h}$ em meio VSES $25 \%$ com adição de uma solução antibiótica e antifúngica, e submetidos a uma lavagem com uma solução de água do mar esterilizada com $0,5 \%$ de hipoclorito de sódio e $200 \mu \mathrm{L} \mathrm{L}^{-1}$ de detergente por 20 segundos. Para avaliar os efeitos da concentração de ágar, os segmentos axênicos foram inoculados em meio ASP 12-NTA com concentrações distintas de ágar que variaram de zero a 1\%. A adição de ágar no meio inibiu o crescimento dos segmentos apicais de ambos os morfos, bem como o crescimento de segmentos intercalares do morfo verde. Observou-se uma tendência geral no crescimento dos explantes, onde a taxa de crescimento foi inversamente proporcional à concentração de ágar. A adição de ágar no meio induziu a formação de três tipos de calo, denominados conforme a região do explante onde se originaram: calo apical, calo basal e calo intermediário. As concentrações de $0,5 \%$ e $0,7 \%$ de ágar foram as concentrações ótimas para indução de calos basais e calos intermediários no morfo verde, respectivamente. A presença de ágar foi essencial para a formação de calos intermediários e apicais. Os resultados indicam que o ágar apresenta um papel na regulação dos processos morfogenéticos em morfos pigmentares de G. domingensis.

Palavras-chave - ágar, calos, Gracilaria domingensis, morfos pigmentares, Rhodophyta

\section{Introdução}

1. Parte da dissertação de mestrado da primeira autora, Programa de Pós-Graduação em Biodiversidade Vegetal e Meio Ambiente, Instituto de Botânica, SP.

2. Instituto de Botânica, Seção de Ficologia, Caixa Postal 3005, 01061-970 São Paulo, SP, Brasil.

3. Universidade de São Paulo, Instituto de Biociências, Departamento de Botânica, Rua do Matão 277, Cidade Universitária, 05508-090 São Paulo, SP, Brasil.

4. Autor para correspondência: nyokoya@pq.cnpq.br

As espécies do gênero Gracilaria Greville são responsáveis por cerca de $60 \%$ da produção mundial de ágar (Tseng 2001) e algumas características fisiológicas, como altas taxas de crescimento e fácil propagação vegetativa, favorecem o seu cultivo (Kain \& Destombe 1995). No Brasil, o extrativismo de algas gracilarióides 
vem aumentando anualmente, e uma avaliação realizada no ano de 2000 revelou que 600 toneladas de Gracilaria spp. foram extraídas das populações naturais do litoral nordeste para a extração de ágar (Oliveira et al. 2000). Além disso, algumas espécies de Gracilaria são utilizadas como biofiltros e como fonte de alimento, principalmente em países asiáticos (De Casabianca et al. 1997).

Gracilaria domingensis (Kützing) Sonder ex Dickie é uma espécie produtora de ágar, mas sua importância econômica deve-se à sua utilização na dieta humana como alimento in natura, e, para esta finalidade, é exportada principalmente para o Japão (Guimarães et al. 1999). Os extratos de G. domingensis apresentam atividade antitumoral (Fernandéz et al. 1989) e possuem compostos fotoprotetores, como, por exemplo, os aminoácidos do tipo micosporina (Cardozo 2007). No Brasil, as populações de G. domingensis apresentam um polimorfismo de cor, aspecto de interesse de vários estudos em laboratório (Guimarães et al. 1999, 2007, Plastino et al. 1999) e na natureza (Guimarães et al. 2003). Esses estudos demonstraram que a manutenção do morfo verde é vantajosa para a espécie, e, embora seja encontrada com menor freqüência, compõe parcela significativa das populações de alguns locais do litoral brasileiro (Guimarães et al. 2003).

Considerando o amplo espectro de utilização comercial da espécie $G$. domingensis e para evitar a redução drástica das populações naturais, é necessário o desenvolvimento de sistemas de cultivo visando à produção sustentável de matéria prima e a conservação das populações naturais. Dentro deste contexto, as técnicas de cultura de tecidos têm sido utilizadas visando a propagação e seleção de linhagens de macroalgas marinhas com características de interesse comercial (Yokoya 2007).

Um aspecto importante no cultivo in vitro de macroalgas marinhas é a adição de um composto para a gelificação do meio de cultura. O ágar é utilizado para a indução de calos, uma vez que, para algumas espécies, o agente gelificante é responsável pelo desenvolvimento dessa estrutura (Jin et al. 1997). No entanto, foram realizados poucos trabalhos sobre os efeitos do agente gelificante e a concentração ótima a ser utilizada para o crescimento e indução de respostas morfogenéticas nas macroalgas marinhas. Robaina et al. (1990) testaram três diferentes concentrações de ágar e observaram que há uma correlação positiva entre a concentração de ágar e a formação de calos, e negativa entre a concentração de ágar e a formação de regenerações em Grateloupia doryphora (Montagne) M. A. Howe. Essa correlação foi também observada em Kappaphycus alvarezii
(Doty) Doty (Reddy et al. 2003) e Gelidiella acerosa (Forsskål) Feldmann \& Hamel (Kumar et al. 2004). Yokoya (1996) testou cinco concentrações de ágar (0,3\% a $0,7 \%$ ) e observou que o crescimento de calos basais de Grateloupia dichotoma J. Agardh e Solieria filiformis (Kützing) Gabrielson foi maior nas concentrações de $0,6 \%$ e $0,7 \%$ de ágar, respectivamente. Bravin et al. (2006) testaram diferentes concentrações de ágar $(0,4 \%$, $0,6 \%, 0,8 \%$ e $1,0 \%$ ) e observaram que as concentrações de $0,8 \%$ e $1,0 \%$ de ágar induziram as maiores taxas de formação de calos em Hypnea musciformis (Wulfen) Lamouroux. Por outro lado, a indução de calos em meio líquido também foi observada para algumas espécies de macroalgas como Agardhiella subulata C. Agardh (Bradley \& Cheney 1990), Pterocladiella capillacea (S. G. Gmelin) Santelices \& Hommersand (Liu et al. 1990), Solieria filiformis (Robledo \& García-Reina 1993, Yokoya 1996) e Gracilaria chilensis Bird, McLachlan \& Oliveira (Collantes et al. 2004).

O objetivo do presente trabalho foi avaliar os efeitos de diferentes concentrações de ágar no crescimento de segmentos do talo e na formação de calos em morfos de coloração verde e vermelha de Gracilaria domingensis.

\section{Material e métodos}

Culturas unialgáceas - Três indivíduos do morfo verde (VD) e três indivíduos do morfo vermelho (VM) de Gracilaria domingensis (Kützing) Sonder ex Dickie proveniente do Banco de Germoplasma de Algas Gracilarióides do IB-USP (Lourenço \& Vieira 2004) foram cultivados em frascos contendo $50 \mathrm{ml}$ de água do mar esterilizada (30-32 ups) enriquecida com 25\% da solução de von Stosch (VSES 25\%) (Edwards 1970, com as concentrações da tiamina, biotina e cianocobalamina reduzidas a $50 \%$, como proposto por Yokoya 2000), em temperatura de $22 \pm 2{ }^{\circ} \mathrm{C}$, irradiância de 50-80 $\mu$ mol de fótons $\mathrm{m}^{-2} \mathrm{~s}^{-1}$ e fotoperíodo de $14 \mathrm{~h}$. A troca do meio de cultura foi realizada semanalmente.

Obtenção de explantes axênicos - Os explantes axênicos dos morfos pigmentares foram obtidos a partir de segmentos do talo com aproximadamente $2 \mathrm{~cm}$ de comprimento provenientes das culturas unialgáceas. Esses segmentos foram cultivados por $48 \mathrm{~h}$ em VSES $25 \%$ acrescido de $100 \mu \mathrm{g} \mathrm{L}^{-1}$ de nistatina (Sigma) e de uma solução antibiótica e antimicótica de Provasoli (Sigma), composta por 20.000 unidades $\mathrm{L}^{-1}$ de penicilina, $20 \mathrm{mg} \mathrm{L}^{-1}$ de estreptomicina e $50 \mu \mathrm{g} \mathrm{L}^{-1}$ de anfotericina. Após esse período, segmentos apicais e segmentos intercalares de $5 \mathrm{~mm}$ de comprimento foram isolados e submetidos a uma lavagem com hipoclorito de sódio $0,5 \%$ (Synth) em água do mar autoclavada e $0,02 \%$ de detergente orgânico (Amway) durante 20 segundos. Essa 
solução foi filtrada em membrana com retenção de partículas maiores do que 0,45 $\mu \mathrm{m}$ (Millipore). Após a lavagem, os segmentos apicais e intercalares foram lavados por três vezes em água do mar autoclavada. Todo o procedimento foi realizado em condições assépticas no interior de uma câmara de fluxo laminar (Veco).

Testes com diferentes concentrações de ágar - Segmentos apicais e segmentos intercalares axênicos de $5 \mathrm{~mm}$ provenientes de ambos os morfos foram cultivados em $40 \mathrm{ml}$ de meio sintético ASP 12-NTA (Iwasaki 1961, modificado segundo Yokoya 2000) contendo ágar purificado e isento de inibidores para microbiologia (Merck, "Microbiology agaragar") nas concentrações de zero, $0,5 \%, 0,6 \%, 0,7 \%, 0,8 \%$, $0,9 \%$ e $1,0 \%$. O meio de cultura $(40 \mathrm{ml})$ foi acondicionado em frascos de vidro do tipo "baby food jars" (Sigma) vedados com tampas autoclaváveis do tipo "magenta B-cap" (Sigma) e autoclavado a $121{ }^{\circ} \mathrm{C}$ durante 15 minutos. Os experimentos foram realizados nas mesmas condições laboratoriais já descritas para as culturas unialgáceas. Cada tratamento foi testado com três repetições simultâneas contendo nove explantes em cada repetição (três explantes de cada indivíduo).

Após oito semanas, foram analisadas a massa da matéria fresca (para o cálculo da taxa de crescimento) e a porcentagem de formação de calos ( $\mathrm{n}^{\circ}$ total de calos/no total de explantes $\times 100 \%$ ). Os explantes foram fotografados com o auxílio de uma câmera fotográfica digital (Sony DSC-S75) e analisados no software Axiovision v. 3.1 (Carl Zeiss).

A taxa de crescimento (TC) foi calculada utilizando-se a seguinte equação:

$\mathrm{TC}=(\ln$ massa final $-\ln$ massa inicial) / (tempo final - tempo inicial)

Análises estatísticas - Os dados foram submetidos à análise de variância (ANOVA, unifatorial e bifatorial) e, quando o resultado da ANOVA foi significativo $(P<0,01)$, foi utilizado o teste de comparação "a posteriori” de Student-NewmanKeuls. As análises estatísticas foram realizadas utilizando o programa SigmaStat (versão 1.0).

\section{Resultados}

Efeitos do ágar nas taxas de crescimento (TC) dos explantes - As TC dos segmentos apicais e intercalares do morfo verde de Gracilaria domingensis foram maiores no tratamento sem adição de ágar, e a menor TC foi observada no tratamento com 1,0\% de ágar (figuras 1A, B). Para o morfo vermelho de $G$. domingensis, a maior TC de segmentos apicais foi observada no tratamento controle e altas concentrações de ágar $(0,9 \%$ e $1,0 \%)$ inibiram o crescimento (figura 1C). As TC dos segmentos intercalares do morfo vermelho não diferiram significativamente entre os tratamentos

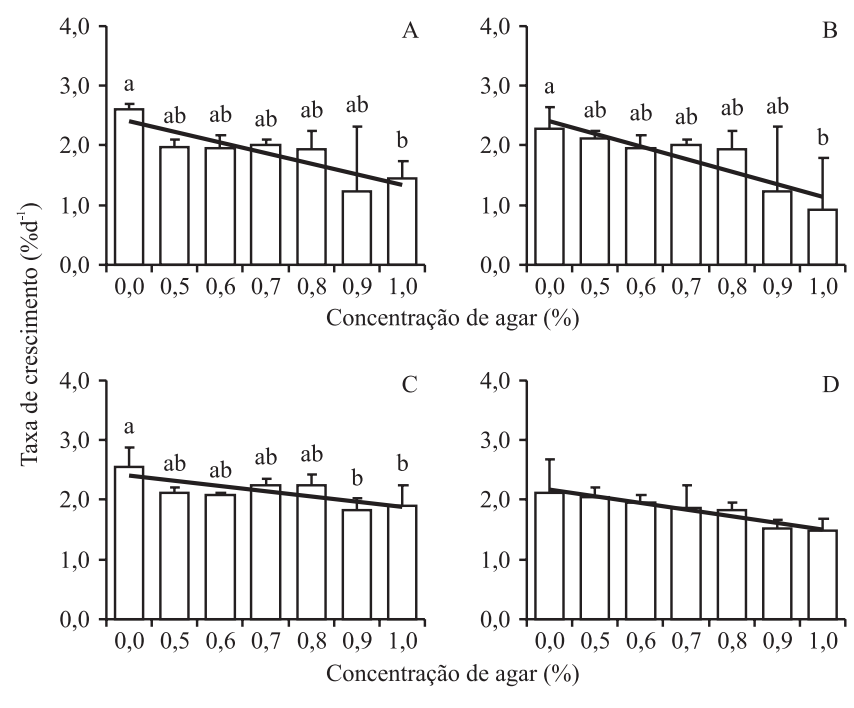

Figura 1. Efeito de diferentes concentrações de ágar na taxa de crescimento $\left(\% \mathrm{~d}^{-1}\right)$ de segmentos apicais $(\mathrm{A}, \mathrm{C})$ e intercalares $(\mathrm{B}, \mathrm{D})$ dos morfos verde $(\mathrm{A}, \mathrm{B})$ e vermelho $(\mathrm{C}, \mathrm{D}) \mathrm{de}$ Gracilaria domingensis após oito semanas de cultivo em meio ASP 12-NTA. Cada valor corresponde à média de três repetições, com nove explantes em cada repetição. As letras indicam tratamentos significativamente diferentes segundo o teste de comparação de Student-Newman-Keuls $(P<0,05)$. As colunas sem letras indicam que o resultado da ANOVA unifatorial $(F)$ não foi significativo. Coeficientes de regressão $\left(\mathrm{r}^{2}\right): \mathrm{A}=0,7620 ; \mathrm{B}=0,8234 ; \mathrm{C}=0,5916 ; \mathrm{D}=0,9762$.

Figure 1. Effect of agar concentrations on growth rates $\left(\% \mathrm{~d}^{-1}\right)$ of apical $(A, C)$ and intercalary $(B, D)$ segments of the green (A, B) and red (C, D) morphs of Gracilaria domingensis cultured in ASP 12-NTA medium for eight weeks. Values presented as average $(n=3)$ with nine explants per replicate. Different letters indicate significant differences using Student-Newman-Keuls's test $(P<0.05)$. Columns without letters indicate that result of one-way ANOVA $(F)$ was not significant. Regression coefficients $\left(\mathrm{r}^{2}\right): \mathrm{A}=0.7620 ; \mathrm{B}=$ 0.8234; $\mathrm{C}=0.5916 ; \mathrm{D}=0.9762$.

testados (figura 1D). Observou-se uma tendência geral no crescimento dos explantes, onde a taxa de crescimento foi inversamente proporcional à concentração de ágar (figuras 1A-D).

Com base na análise de variância bifatorial, verificou-se que tanto as concentrações de ágar quanto a cor do morfo influenciaram as taxas de crescimento de segmentos apicais, porém não houve interação entre esses dois fatores (tabela 1). Para os segmentos intercalares, a análise de variância bifatorial mostrou que apenas a concentração de ágar influenciou a taxa de crescimento (tabela 1 ). 
Tabela 1. Análise de variância bifatorial $(F)$ da taxa de crescimento dos segmentos apicais e intercalares dos morfos verde e vermelho de Gracilaria domingensis após oito semanas de cultivo em meio ASP 12-NTA com diferentes concentrações de ágar. Variáveis: $\mathrm{A}=$ concentrações de ágar; $\mathrm{B}=\operatorname{morfos}(P=$ probabilidade $)$. Negrito $=$ efeito significativo.

Table 1. Bifactorial analysis of variance $(F)$ of growth rates of apical and intercalary segments of the green and red morphs of Gracilaria domingensis cultured in ASP 12-NTA medium with different agar concentrations for eight weeks. Variables: A= agar concentrations; $\mathrm{B}=$ morphs $(P=$ probability $)$. Letters and numbers in bold correspond to significant effects.

\begin{tabular}{cccrr}
\hline Tipo de segmento do talo & Efeito & Graus de liberdade & $F$ & $P$ \\
\hline \multirow{2}{*}{ Apical } & $\mathbf{A}$ & $\mathbf{6}$ & $\mathbf{1 0 , 0 7 3}$ & $<\mathbf{0 , 0 0 0 1}$ \\
& $\mathbf{B}$ & $\mathbf{1}$ & $\mathbf{6 , 8 3 8}$ & $\mathbf{0 , 0 1 4 7}$ \\
& Interação A/B & 6 & 0,918 & 0,4979 \\
Intercalar & $\mathbf{A}$ & $\mathbf{6}$ & $\mathbf{4 , 5 6 8}$ & $\mathbf{0 , 0 0 2 4}$ \\
& B & 1 & 3,437 & 0,0743 \\
& Interação A/B & 6 & 0,596 & 0,7310 \\
\hline
\end{tabular}

Efeitos do ágar na formação de calos - Três tipos de calos foram induzidos pelos diferentes tratamentos para ambos os morfos de G. domingensis: calo basal (formado na região distal do explante, onde foi realizada a secção do explante no início dos experimentos), calo apical (formado na região apical dos segmentos apicais) e calo intermediário (formado nas regiões intermediárias do explante) (figuras 2A-C).

Nos segmentos apicais do morfo verde de $G$. domingensis houve a formação dos três tipos de calos. As maiores porcentagens de calos basais foram observadas nos tratamentos controle e $0,5 \%$ de ágar, entretanto, altas concentrações de ágar $(0,9 \%$ e $1 \%)$ inibiram a formação desses calos (figura 3A). O tratamento com $0,7 \%$ de ágar estimulou a formação de calos intermediários, enquanto que os tratamentos controle e com 1\% de ágar inibiram a formação desse tipo de calo (figura 3B). A presença do ágar no meio de cultura é essencial para a formação de calos apicais, uma vez que estes calos não se formaram em explantes cultivados sem ágar (tratamento controle), e não foram observadas diferenças significativas entre as diferentes concentrações de ágar na formação dos calos apicais (figura 3C). Os segmentos intercalares do morfo verde desenvolveram somente calos basais e calos intermediários, e as porcentagens de formação destes dois tipos de calos não diferiram significativamente entre os tratamentos testados, apesar da ausência de ágar inibir a formação de calos intermediários nos segmentos intercalares (figuras 4A, B).

Nos segmentos apicais do morfo vermelho de G. domingensis, não foram observadas diferenças significativas entre os tratamentos que induziram a formação de calos basais (figura 5A), calos intermediários (figura 5B) e calos apicais (figura 5C). O tratamento controle (sem ágar) inibiu a formação de calos intermediários e apicais. Nos segmentos intercalares do morfo vermelho, foram observados somente calos basais,

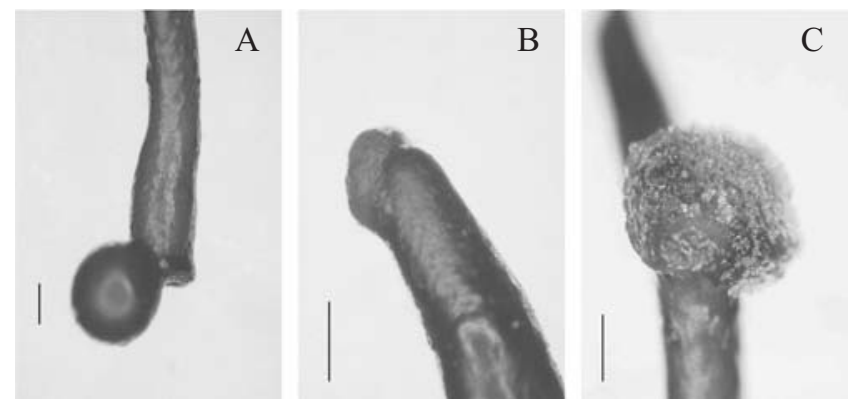

Figura 2. Aspecto geral dos diferentes tipos de calos formados no morfo vermelho após oito semanas de cultivo em meio ASP 12-NTA. (A) calo basal formado em um segmento intercalar cultivado no tratamento com $0,5 \%$ de ágar. (B) calo apical formado em um segmento apical cultivado no tratamento com $0,6 \%$ de ágar. (C) calo intermediário formado em um segmento intercalar cultivado no tratamento com $0,5 \%$ de ágar. Barra $=0,6 \mathrm{~mm}$.

Figure 2. Callus type developed from red morph of Gracilaria domingensis cultured in ASP 12-NTA medium for eight weeks. (A) basal callus in intercalary segment cultured with $0.5 \%$ of agar. (B) apical callus in apical segment cultured with $0.6 \%$ of agar. (C) intermediate callus in intercalary segment cultured with $0.5 \%$ of agar. $\mathrm{Bar}=0.6 \mathrm{~mm}$. 

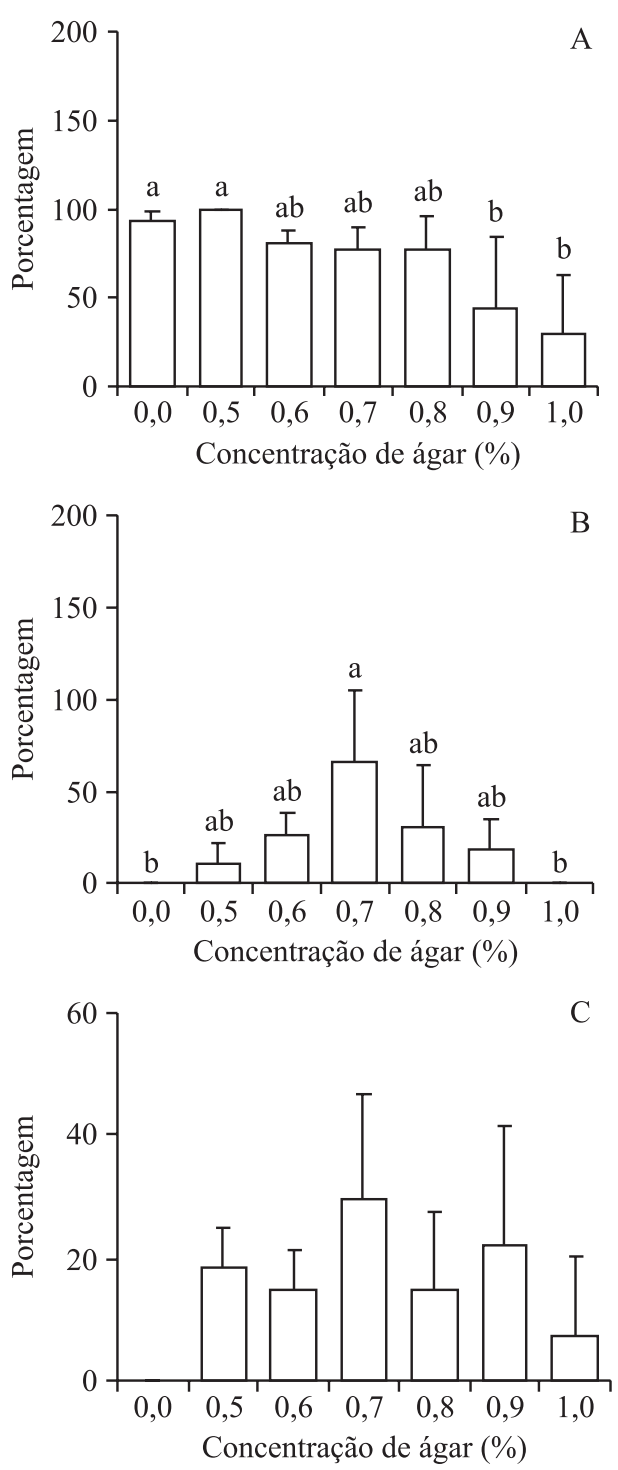

Figura 3. Efeito de diferentes concentrações de ágar na porcentagem de formação de calos (no de calos / no total de explantes $\times 100 \%$ ) em segmentos apicais (A-C) do morfo verde de Gracilaria domingensis após oito semanas de cultivo em meio ASP 12-NTA. Cada valor corresponde a média de três repetições com nove explantes em cada repetição. As letras indicam tratamentos significativamente diferentes segundo o teste de comparação de Student-Newman-Keuls $(P<0,05)$. As colunas sem letras indicam que o resultado da ANOVA unifatorial $(F)$ não foi significativo.

Figure 3. Effect of agar concentrations on the percentage of callus induction (number of callus / total number of explants $\times 100 \%$ ) of apical segments (A-C) of the green morph of Gracilaria domingensis cultured in ASP 12-NTA medium for eight weeks. Values presented as average $(n=3)$ with nine explants per replicate. Different letters indicate significant differences using Student-Newman-Keuls's test $(P<0.05)$. Columns without letters indicate that result of one-way ANOVA $(F)$ was not significant.

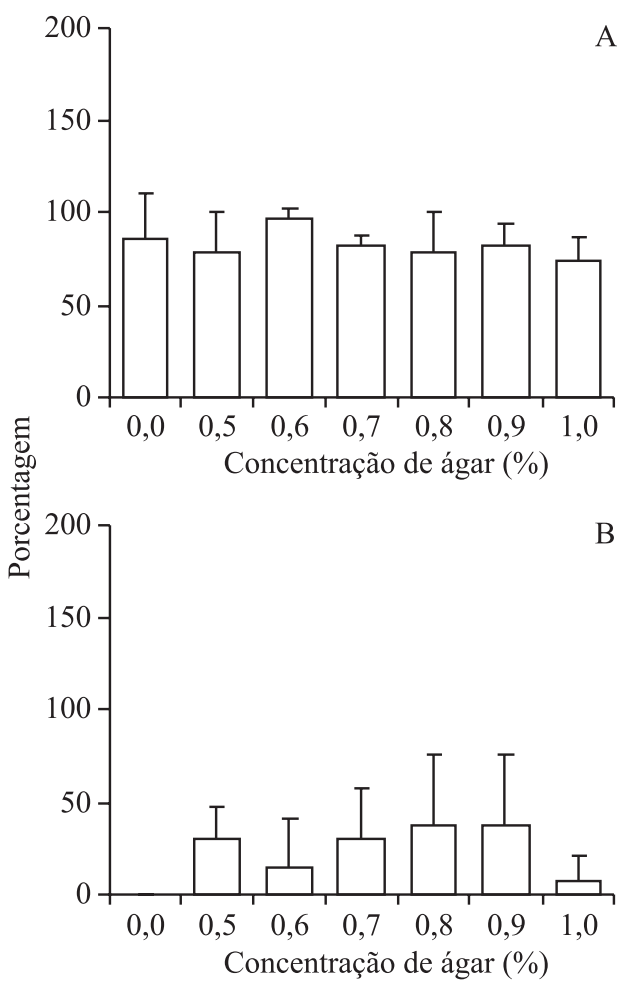

Figura 4. Efeito de diferentes concentrações de ágar na porcentagem de formação de calos (no de calos / no total de explantes $\times 100 \%$ ) em segmentos intercalares (A-B) do morfo verde de Gracilaria domingensis após oito semanas de cultivo em meio ASP 12-NTA. Cada valor corresponde a média de três repetições com nove explantes em cada repetição. As análises de variância unifatorial indicaram que as diferenças entre os tratamentos não foram significativas.

Figure 4. Effect of agar concentrations on the percentage of callus induction (number of callus / total number of explants $\times 100 \%)$ of intercalary segments (A-B) of the green morph of Gracilaria domingensis cultured in ASP 12-NTA medium for eight weeks. Values presented as average $(n=3)$ with nine explants per replicate. No significant differences were detected in all data after unifactorial ANOVA.

mas as porcentagens não diferiram significativamente entre os tratamentos testados (figura 5D).

A análise de variância bifatorial evidenciou que apenas as concentrações de ágar influenciaram na porcentagem de formação de calos basais em segmentos apicais e intercalares (tabela 2).

Para os calos apicais (tabela 3), a análise de variância bifatorial mostrou que apenas a cor do morfo influenciou a porcentagem de formação dos mesmos. O morfo verde apresentou taxa de formação de calos apicais superior ao morfo vermelho em todos os tratamentos testados. 


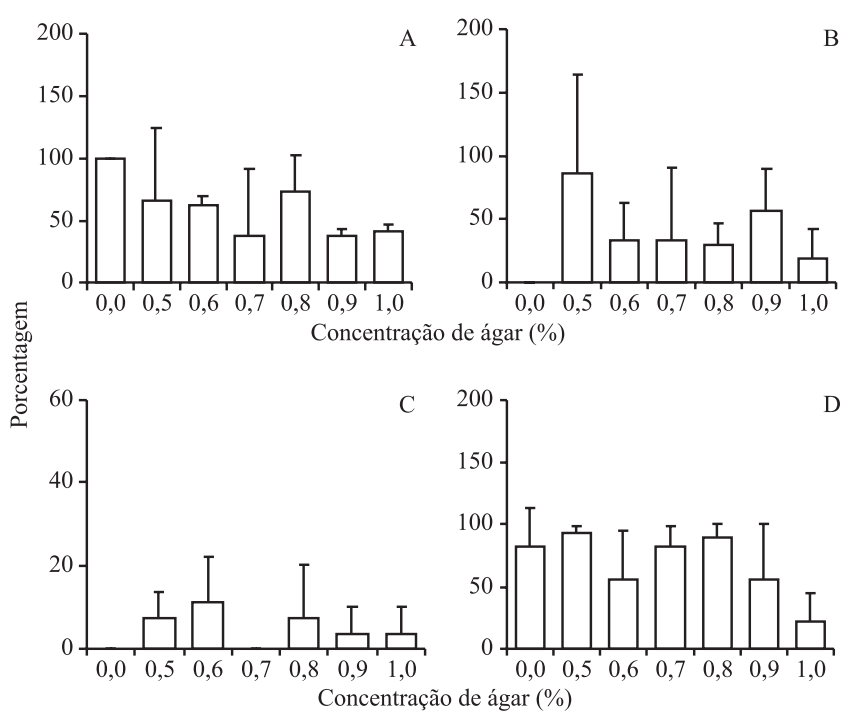

Figura 5. Efeito de diferentes concentrações de ágar na porcentagem de formação de calos (n⿳o de calos / no total de explantes $\times 100 \%$ ) em segmentos apicais (A-C) e intercalares (D) do morfo vermelho de Gracilaria domingensis após oito semanas de cultivo em meio ASP 12-NTA. Cada valor corresponde a média de três repetições com nove explantes em cada repetição. As análises de variância unifatorial indicaram que as diferenças entre os tratamentos não foram significativas.

Figure 5. Effect of agar concentrations on the percentage of callus induction (number of callus / total number of explants $\times$ $100 \%$ ) of apical (A-C) and intercalary (D) segments of the red morph of Gracilaria domingensis cultured in ASP 12-NTA medium for eight weeks. Values presented as average $(n=3)$ with nine explants per replicate. No significant differences were detected in all data after unifactorial ANOVA.
Tabela 3: Análise de variância bifatorial $(F)$ da formação de calos apicais dos segmentos apicais dos morfos verde e vermelho de Gracilaria domingensis, após oito semanas de cultivo em meio ASP 12-NTA com diferentes concentrações de ágar. Variáveis: $\mathrm{A}=$ concentrações de ágar; $\mathrm{B}=$ morfos $(P=$ probabilidade $)$. Negrito $=$ efeito significativo.

Table 3. Bifactorial analysis of variance $(F)$ of apical callus formation from apical segments of the green and red morphs of Gracilaria domingensis cultured in ASP 12-NTA medium with different agar concentrations for eight weeks. Variables: $\mathrm{A}=$ agar concentrations; $\mathrm{B}=$ morphs $(P=$ probability $)$. Letters and numbers in bold correspond to significant effects.

\begin{tabular}{ccrc}
\hline Efeito & Graus de liberdade & \multicolumn{1}{c}{$F$} & $P$ \\
\hline A & 6 & 1,61 & 0,1811 \\
B & $\mathbf{1}$ & $\mathbf{1 1 , 1 1}$ & $\mathbf{0 , 0 0 2 4}$ \\
Interação A/B & 6 & 1,52 & 0,2085 \\
\hline
\end{tabular}

\section{Discussão}

Os resultados obtidos com relação à TC dos explantes dos morfos verde e vermelho de Gracilaria domingensis nas diferentes concentrações de ágar seguiram um padrão no qual as TC de segmentos apicais de ambos os morfos foram maiores no tratamento controle (sem adição de ágar), e as menores foram observadas nos tratamentos com altas concentrações de ágar ( $0,9 \%$ e $1,0 \%$ de ágar). Segundo Paiva et al. (1999), a concentração de ágar no meio de cultura deve ser mantida baixa, o suficiente para manter os explantes na superfície do meio, uma vez

Tabela 2. Análise de variância bifatorial $(F)$ da taxa de formação de calos basais dos segmentos apicais e intercalares dos morfos verde e vermelho de Gracilaria domingensis, após oito semanas de cultivo em meio ASP 12-NTA com diferentes concentrações de ágar. Variáveis: $\mathrm{A}=$ concentrações de ágar; $\mathrm{B}=\operatorname{morfos}(P=$ probabilidade $)$. Negrito $=$ efeito significativo.

Table 2. Bifactorial analysis of variance $(F)$ of basal callus formation from apical and intercalary segments of the green and red morphs of Gracilaria domingensis cultured in ASP 12-NTA medium with different agar concentrations for eight weeks. Variables: $\mathrm{A}=$ agar concentrations; $\mathrm{B}=$ morphs $(P=$ probability $)$. Letters and numbers in bold correspond to significant effects.

\begin{tabular}{ccccr}
\hline Tipo de segmento do talo & Efeito & Graus de liberdade & $F$ & $P$ \\
\hline Apical & $\mathbf{A}$ & $\mathbf{6}$ & $\mathbf{3 , 9 9 5}$ & $\mathbf{0 , 0 0 5 2}$ \\
& $\mathrm{B}$ & 1 & 2,065 & 0,1618 \\
\multirow{2}{*}{ Intercalar } & Interação A/B & 6 & 0,768 & 0,6012 \\
& $\mathbf{A}$ & $\mathbf{6}$ & $\mathbf{4 8 8 , 1 6 1}$ & $<\mathbf{0 , 0 0 0 1}$ \\
& $\mathrm{B}$ & 1 & 0,0402 & 0,8426 \\
& Interação A/B & 6 & 0,0228 & 0,9999 \\
\hline
\end{tabular}


que altas concentrações de ágar limitam o crescimento pela redução na disponibilidade de água e absorção de nutrientes.

A porcentagem de formação de calos basais foi alta nos dois tipos de explantes estudados para ambos os morfos de Gracilaria domingensis. O desenvolvimento dessa estrutura em rodofíceas está relacionado à injúria provocada pela secção feita no explante (Robaina et al. 1992). Essa resposta foi observada no presente estudo, com a formação de calos basais tanto em meio líquido quanto em meio sólido. O processo de formação de calos como resposta a uma lesão foi também observado em outras espécies de rodofíceas (Polne-Fuller \& Gibor 1987): Laurencia sp. (Robaina et al. 1992), Grateloupia filiformis (J.V. Lamouroux) C. Agardh (Yokoya et al. 1993), Grateloupia dichotoma J. Agardh (Yokoya \& Handro 1996), Meristotheca papulosa (Montagne) J. Agardh (Huang \& Fujita 1997), Gracilaria vermiculophylla (Ohmi) Papenfuss (Yokoya et al. 1999), Kappaphycus alvarezii (Reddy et al. 2003), Gracilaria tenuistipitata Chang et Xia e Gracilaria perplexa Byrne et Zuccarello (Yokoya et al. 2004).

A concentração ótima de ágar para a formação de calos basais em segmentos apicais do morfo verde de Gracilaria domingensis foi 0,5\%. Resultados similares foram observados para a indução de calos basais de Gracilaria vermiculophylla (Yokoya et al. 1999) e calos apicais de Hypnea musciformis (Yokoya et al. 2003). Entretanto, baixas concentrações de ágar $(0,4 \%)$ induziram a formação de calos basais em Grateloupia dichotoma (Yokoya \& Handro 1996), calos apicais em Gracilariopsis tenuifrons (Bird \& Oliveira) Fredericq \& Hommersand (Yokoya 2000) e explantes filamentosos em Solieria filiformis (Yokoya \& Handro 2002).

A concentração ótima de ágar para a formação de calos intermediários no morfo verde de Gracilaria domingensis foi $0,7 \%$, corroborando os resultados obtidos em Gracilaria tenuistipitata e $G$. perplexa (Yokoya et al. 2004). Entretanto, Chondrus crispus Stackhouse (Chen \& Taylor 1978), Gracilaria verrucosa (Hudson) Papenfuss (Kaczyna \& Megnet 1993), Grateloupia doryphora (Garcia-Jimenez et al. 1998) e Gelidiella acerosa (Kumar et al. 2004) apresentaram a maior taxa de formação de calos em uma concentração maior ( $0,8 \%$ de ágar). A formação de calos intermediários é menos freqüente do que a de calos basais. No presente estudo, a formação desses calos intermediários pode estar relacionada à dessecação, uma vez que o explante ficou exposto ao ar durante todo o período experimental. Os resultados observados em calos intermediários de Gracilaria domingensis são similares aos descritos para G. tenuistipitata e $G$. perplexa (Yokoya et al. 2004).

As diferentes concentrações de ágar não influenciaram a porcentagem de formação de calos apicais em ambos os morfos pigmentares de Gracilaria domingensis. A formação dessa estrutura também pode estar relacionada à dessecação, como foi observado nos calos intermediários, e corroboram os resultados obtidos para calos apicais de Hypnea musciformis (Yokoya et al. 2003, Bravin 2005) e Gracilaria tenuistipitata (Yokoya et al. 2004). A formação de calos apicais foi descrita para outras espécies, em decorrência de outros fatores tais como estímulo mecânico para Solieria filiformis (Robledo \& García-Reina 1993) e a presença de fitorreguladores para Gracilariopsis tenuifrons (Yokoya 2000) e Gracilaria perplexa (Yokoya et al. 2004).

Neste trabalho, a principal diferença entre os morfos verde e vermelho de Gracilaria domingensis está relacionada à porcentagem de formação de calos. O morfo verde apresentou porcentagens maiores do que o morfo vermelho, tanto para os segmentos apicais quanto para os segmentos intercalares. Além disso, os segmentos intercalares do morfo verde apresentaram dois tipos de calos (calos basais e calos intermediários), enquanto que no morfo vermelho foi observada apenas a formação de calos basais. Esses resultados mostram que os morfos apresentam respostas distintas quando cultivados em diferentes concentrações de ágar, e que o ágar pode influenciar as respostas morfogenéticas em morfos pigmentares de Gracilaria domingensis.

Agradecimentos - Ao Conselho Nacional de Desenvolvimento Científico e Tecnológico (CNPq), pela concessão de bolsa de mestrado para a primeira autora e bolsas de produtividade em pesquisa para a segunda e terceira autoras.

\section{Referências bibliográficas}

BRADLEY, P.M. \& CHENEY, D.P. 1990. Some effects of plant regulators on tissue cultures of the marine red alga Agardhiella subulata (Gigartinales, Rhodophyta). Hydrobiologia 204/205:353-360.

BRAVIN, I.C. 2005. Micropropagação e potencial biotecnológico de Hypnea musciformis (Gigartinales Rhodophyta). Tese de doutorado, Universidade Federal do Rio de Janeiro, Rio de Janeiro.

BRAVIN, I.C., VALENTIN, Y.Y. \& YOKOYA, N.S. 2006. Formação de calos e regeneração de segmentos apicais de Hypnea musciformis (Wulfen) Lamouroux (Gigartinales, Rhodophyta): obtenção de culturas axênicas e efeitos de diferentes concentrações de ágar. Revista Brasileira de Botânica 29:175-182. 
CARDOZO, K.H.M. 2007. Estudos de compostos fotoprotetores da radiação ultravioleta em algas: ácidos tipo micosporinas (MAAs). Tese de Doutorado, Universidade de São Paulo, São Paulo.

CHEN, L.C.M. \& TAYLOR, A.R.A. 1978. Medullary tissue culture of the red alga Chondrus crispus. Canadian Journal of Botany 56:883-886.

COLlantes, G., MElO, C. \& CANDIA, A. 2004. Micropropagation by explants of Gracilaria chilensis Bird, McLachlan and Oliveira. Journal of Applied Phycology 16:203-213.

DE CASABIANCA, M.L., MARINHO-SORIANO, E. \& LAUGIER, T. 1997. Growth of Gracilaria bursapastoris in a Mediterranean Lagoon: Thau, France. Botanica Marina 40:29-37.

EDWARDS, P. 1970. Illustrated guide to the seaweeds and seagrasses in the vicinity of Porto Aransas, Texas. Contribution of Marine Sciences Austin 15:1-228.

FERNÁNDEZ, L.E., VALIENTE, O.G., MAINARDI, V., BELLO, J.L., VÉLEZ, H. \& ROSADO, A. 1989. Isolation and characterization of antitumor active agar-type polysaccharide of Gracilaria domingensis. Carbohydrate Research 190:77-83.

GARCIA-JIMENEZ，P., RODRIGO, M. \& ROBAINA, R.R. 1998. Influence of plant growth regulators, polyamines and glycerol on growth and morphogenesis of carposporelings of Grateloupia cultured in vitro. Journal of Applied Phycology 10:95-100.

GUimarÃES, M., PlAStinO, E.M. \& DESTOMBE, C. 2003. Green mutant frequency in natural populations of Gracilaria domingensis (Gracilariales, Rhodophyta) from Brazil. European Journal of Phycology 38:165-169.

GUIMARÃES, M., PLASTINO, E.M. \& OLIVEIRA, E.C. 1999. Life history, reproduction and growth of Gracilaria domingensis (Gracilariales, Rhodophyta) from Brazil. Botanica Marina 42:481-486.

GUIMARÃES, M., VIANA, A.G., DUARTE, M.E.R., ASCÊNCIO, S.D., PLASTINO, E.M. \& NOSEDA, M.D. 2007. Low-molecular-mass carbohydrates and soluble polysaccharides of green and red morphs of Gracilaria domingensis (Gracilariales, Rhodophyta). Botanica Marina 50:314-317.

HUANG, W. \& FUJITA, Y. 1997. Callus induction and thallus regeneration of the red alga Meristotheca papulosa (Rhodophyta, Gigartinales). Botanica Marina 40:55-61.

IWASAKI, H. 1961. The life cycle of Porphyra tenera in vitro. The Biological Bulletin 121:173-187.

JIN, H., SEO, G., CHO, Y.C., HWANG, E., SOHN, C.H. \& HONG, Y. 1997. Gelling agents for tissue culture of the seaweed Hizikia fusiformis. Journal of Applied Phycology 9:489-493.

KACZYNA, F. \& MEGNET, R. 1993. The effects of glycerol and plant growth regulators on Gracilaria verrucosa (Gigartinales, Rhodophyceae). Hydrobiologia 268: 57-64.
KAIN, J.M. \& DESTOMBE, C. 1995. A review of the life history, reproduction and phenology of Gracilaria. Journal of Applied Phycology 7:269-281.

KUMAR, G.R., REDDY, C.R.K., GANESAN, M., THIRUPPATHI, S., DIPAKKORE, S., ESWARAN, K., SUBBA RAO, P.V. \& JHA, B. 2004. Tissue culture and regeneration of thallus from callus of Gelidiella acerosa (Gelidiales, Rhodophyta). Phycologia 43:596-602.

LIU, X., ROCHAS, C. \& KLOAREG, B. 1990. Callus culture of Pterocladiella capillacea (Rhodophyta) and analysis of cell wall polysaccharides. Journal of Applied Phycology 2:297-303.

LOURENÇO, S.O. \& VIEIRA, A.A.H. 2004. Culture collection of microalgae in Brazil: progress and constraints. Nova Hedwigia 79:149-173.

OLIVEIRA, E.C., ALVEAL, K. \& ANDERSON, R. 2000. Mariculture of agar-producing gracilarioid red algae. Reviews in Fisheries Science 8:345-378.

PAIVA, P.D.O., PASQUAL, M. \& PAIVA, R. 1999. Efeito de concentrações de ágar e níveis de $\mathrm{pH}$ na propagação in vitro de crisântemo. Ceres 46:141-148.

PLASTINO, E.M., GUIMARÃES, M., MATIOLI, S.R. \& OLIVEIRA, E.C. 1999. Codominant inheritance of polymorphic color variants of Gracilaria domingensis (Gracilariales, Rhodophyta). Genetic Molecular Biology 22:105-108.

POLNE-FULlER, M. \& GIBOR, A. 1987. Calluses and callus-like growth in seaweeds: induction and culture. Hydrobiologia 151/152:131-138.

REDDY, C.R.K., KUMAR, G.R.K., SIDDHANTA, A.K. \& TEWARI, A. 2003. In vitro somatic embryogenesis and regeneration of somatic embryos from pigmented callus of Kappaphycus alvarezii (Doty) Doty (Rhodophyta, Gigartinales). Journal of Phycology 39:610-616.

ROBAINA, R.R., GARCIA, P., GARCÍA-JIMENEZ, P. \& LUQUE, A. 1990. Morphogenetic effect of glycerol on tissue cultures of the red seaweed Grateloupia doryphora. Journal of Phycology 2:137-143.

ROBAINA, R.R., GARCÍA-JIMENEZ, P. \& LUQUE, A. 1992. The growth pattern and structure of callus from the red alga Laurencia sp. (Rhodophyta, Ceramiales) compared to shoot regeneration. Botanica Marina 35:267-272.

ROBLEDO, D.R. \& GARCÍA-REINA, G. 1993. Apical callus formation in Solieria filiformis (Gigartinales, Rhodophyta) cultured in tanks. Hydrobiologia 260/ 261:401-406.

TSENG, C.K. 2001. Algal biotechnology industries and research activities in China. Journal of Applied Phycology 13:375-380.

YOKOYA, N.S. 1996. Controle do desenvolvimento e da morfogênese por auxinas e citocininas em três espécies de rodofíceas: Gracilariopsis tenuifrons, Grateloupia dichotoma e Solieria filiformis. Tese de doutorado, Universidade de São Paulo, São Paulo. 
YOKOYA, N.S. 2000. Apical callus formation and plant regeneration controlled by plant growth regulators on axenic culture of the red alga Gracilariopsis tenuifrons (Gracilariales, Rhodophyta). Phycological Research 48:133-142.

YOKOYA, N.S. 2007. Compostos biologicamente ativos de algas marinhas e perspectivas de aplicação em novos fármacos: a importância da propagação in vitro de macroalgas marinhas como subsídio para a produção sustentável de seus derivados, com ênfase nas Rhodophyta. In A botânica no Brasil: pesquisa, ensino e políticas públicas ambientais (L.M. Barbosa \& N.A. Santos Júnior, orgs.). Secretaria do Meio Ambiente, São Paulo, v.1, p.155-158.

YOKOYA, N.S., GUIMARÃES, S.M.P.B. \& HANDRO, W. 1993. Development of callus-like structures and plant regeneration in thallus segments of Grateloupia filiformis Kützing (Rhodophyta). Hydrobiologia 260/261:407-413.

YOKOYA, N.S. \& HANDRO, W. 1996. Effects of auxins and citokinin on tissue culture of Grateloupia dichotoma (Gigartinales, Rhodophyta). Hydrobiologia 326/327:393-400.
YOKOYA, N.S. \& HANDRO, W. 2002. Effects of plant growth regulators and culture medium on morphogenesis of Solieria filiformis (Rhodophyta) cultured in vitro. Journal of Applied Phycology 14:97-102.

YOKOYA, N.S., KAKITA, H., OBIKA, H. \& KITAMURA, T. 1999. Effects of environmental factors and plant growth regulators on growth of the red alga Gracilaria vermiculophylla from Shikoku Island, Japan. Hydrobiologia 398:339-347.

YOKOYA, N.S., PLASTINO, E.M. \& ARTEL, R. 2003. Physiological responses and pigment characterization of two colour strains of the carrageenophyte Hypnea musciformis (Rhodophyta). In Proceedings of the XVII ${ }^{\text {th }}$ International Seaweed Symposium (A.R.O. Chapman, R.J. Anderson, V.J. Vreeland \& J.R. Davison, eds.). Oxford University Press, New York, p.425-433.

YOKOYA, N.S., WEST, J.A. \& LUCHI, A.E. 2004. Effects of plants growth regulators on callus formation, growth and regeneration in axenic tissue cultures of Gracilaria tenuispitata and Gracilaria perplexa (Gracilariales, Rhodophyta). Phycological Research 52:244-25. 